\title{
Determination of some chemical and microbiological characteristics of Kaymak*
}

\author{
By Ayșe Sibel Akalın*, Sıddık Gönç, Gülfem Ünal and Sevtap Ökten \\ Ege University, Faculty of Agriculture, Department of Dairy Technology, 35100, Bornova, \\ İmir, TURKEY. E-mail:sakalin21@yahoo.com
}

This research was presented at the $3^{\text {rd }}$ Euro Fed Lipid Congress on Oils, Fats and Lipids in a Changing World, 5-8 September 2004, Edinburgh University, Scotland.

\section{RESUMEN}

Determinación de algunas características químicas y microbiológicas del Kaymak

Kaymak es una clase de crema concentrada, que se fabrica tradicionalmente de la leche del búfalo o de la vaca en Turquía. Se consume generalmente con la miel en el desayuno y en algunos postres turcos tradicionales. El objetivo de este estudio fue determinar algunas características químicas y microbiológicas del kaymak. Las muestras fueron obtenidas de diversas instalaciones lecheras productoras de kaymak de leche de vaca y de mercados locales situados en İzmir. Se analizó el contenido en sólidos totales y grasas, acidez, pH y valores de peróxido, además del conteo de tan bien como cuentas de las bacterias coliformes, E. coli, levadura y mohos, y estafilococos. Las características químicas de las muestras fueron generalmente aceptables para el Turkish Food Codex. Sin embargo, las características microbiológicas de algunas muestras fueron muy malas. La industria del kaymak debe ser extremadamente cuidadosa durante la fabricación y el almacenaje del producto.

PALABRAS-CLAVE: Características químicas - Características microbiológicas - Kaymak

\section{SUMMARY}

Determination of some chemical and microbiological characteristics of Kaymak

Kaymak is a kind of concentrated cream, which is traditionally manufactured from buffalo or cow's milk in Turkey. It is generally consumed with honey at breakfast and some traditional Turkish desserts. The aim of this study was to determine some chemical and microbiological properties of kaymak. The samples were obtained from different dairy plants producing kaymak from cow's milk and local markets located in İzmir. They were examined for total solids and fat contents, acidity, $\mathrm{pH}$ and peroxide values, as well as counts of coliform bacteria, E. coli, yeast and moulds, and Staphylococci.

Chemical characteristics of the samples were generally favorable for Turkish Food Codex. However, microbiological properties of some samples were very poor. Careful considerations should be given by the kaymak industry during manufacturing and storage of the product.

KEY-WORDS: Chemical characteristics - Kaymak Microbiological characteristics.

\section{INTRODUCTION}

Kaymak is traditionally produced from water buffalo or cow's milk in Turkey. It is the main component of some Turkish desserts such as kadayif and baklava. Consumers because of its high fat content $(9.3 \%)$ and white color prefer Kaymak manufactured from water buffalo milk. As buffalo milk is not always available, it has become necessary to use cow's milk mixed with cream in the manufacturing of kaymak, which makes the production of kaymak possible in all seasons. In this study, all kaymak samples were manufactured from cow's milk.

Milk fat plays an important role in physical properties, flavour and nutritional values of milk and other dairy products. Moreover, milk fat is a good energy source and contains medium chain fatty acids, essential unsaturated fatty acids as linoleic and arachidonic acids and fat-soluble vitamins ( $A$, $D, E$ and $K)$. Because of these properties, it has great importance in nutrition physiology (Fox, 1995; Metin, 1998).

Kaymak is different from other well-known milk fat based products such as butter, ghee, sanma, meshho, samin and samuli in terms of composition and shelf life. Firstly, kaymak contains higher amount of moisture and lower milk fat. In addition, no fermentation process is used for the manufacturing of kaymak. These differences affect the shelf life of kaymak. Kaymak should be consumed within one week because it is a non fermented product, whereas the shelf life of the other mentioned products was reported as 6-8 months (Sserunjogi et al., 1998). The possibility of microbial contamination of the product makes it necessary to consume the product in a short time.

There is no international study on the properties of commercial kaymak samples except CLA content of kaymak (Akalın et al. 2005) although some studies have been published on the characteristics of different milk fat based products (Kaya, 2000; Hayaloglu and Konar, 2001; Sagdiç et al. 2004). Therefore, the aim of this study was to determine some chemical properties such as total solids, fat, acidity, $\mathrm{pH}$ and peroxide value as well as microbiological characteristics such as coliform bacteria, E. coli, staphylococci and yeast and 
moulds in commercial kaymak samples produced in İzmir, Turkey.

\section{EXPERIMENTAL}

\subsection{Materials}

Kaymak samples were obtained from five different dairy plants producing kaymak from cow's milk in İzmir, Turkey. Kaymak has a special manufacturing process as a traditional product. (This process was carried out in Akgül dairy products plant Çiğli, İzmir, Turkey). Firstly, raw milk $(100 \mathrm{~L})$ containing $4 \%$ fat was heated at $90{ }^{\circ} \mathrm{C}$ for $8-10$ min. $13 \mathrm{~kg}$ of cream (70\% fat) heated at $85^{\circ} \mathrm{C}$ were added and the mixture was stirred for $5 \mathrm{~min}$ and heated up to $87^{\circ} \mathrm{C}$. The mixture was poured into stainless steal pans of $6 \mathrm{~L}$ and kept at $75-80^{\circ} \mathrm{C}$ for about 2 hours until the foam disappeared. Then, the mixture was cooled to $20-25^{\circ} \mathrm{C}$ and stored at 4 ${ }^{\circ} \mathrm{C}$ for 8-12 hours in order to ripening. Finally, the kaymak layer formed at the upper part was cut and separated from the skim milk layer. It was shaped into small rolls and packaged in plastic cups. The samples and four other commercial kaymak samples were brought to the laboratory under cold conditions and stored in a refrigerator until analysis. Kaymak samples were manufactured twice in each plant. Therefore, ten samples were obtained for the analysis. All analysis were made in duplicate and completed within $2 \mathrm{~d}$.

\subsection{Methods}

\subsubsection{Chemical Analysis}

Total solids: Total solids content was determined by drying samples at $105^{\circ} \mathrm{C}$ for 3-4 hours (AOAC, 1990).

Titratable acidity: It was determined in $10 \mathrm{~g}$ kaymak diluted with $10 \mathrm{ml}$ of distilled water by titrating with $0.1 \mathrm{~N} \mathrm{NaOH}$ and was expressed as \% lactic acid.

pH: It was determined by using a $\mathrm{pH}$ meter combined with a glass electrode (Model SS-3, Beckman, Fullerton, CA, USA)

Fat content: Fat contents were measured according to Gerber butyrometric method (AOAC, 1990).

Peroxide value: Peroxide values of samples were measured according to AOAC (1990).

\subsubsection{Microbiological Analysis}

10 gram of each kaymak sample was homogenized with $90 \mathrm{ml}$ of $0.15 \%(\mathrm{w} / \mathrm{v})$ sterilized peptone water (Oxoid, Hampshire, UK) and mixed until uniform. Subsequent serial dilutions were prepared in sterile $9 \mathrm{ml} 0.15 \%(\mathrm{w} / \mathrm{v})$ peptone water and desired microorganisms were numbered. Plates containing twenty-five to 250 colonies were numbered and recorded as colony forming units (CFU) per gram of sample.

Numbering of Coliform Bacteria: The counts of coliform bacteria were taken on Violet Red Bile Agar (VRB) (Merck, Darmstad, Germany) after incubating the plates aerobically at $37^{\circ} \mathrm{C}$ for $24 \mathrm{~h}$ (Wehr and Frank, 2004).

Determination of $E$. coli : First gas formation was observed in the samples on Brillant Green Bile Broth (BGBB) after incubating at $37{ }^{\circ} \mathrm{C}$ for $24 \mathrm{~h}$. Samples which formed gas in Durham tubes were inoculated to nutrient broth and incubated aerobically at $37^{\circ} \mathrm{C}$ for $24 \mathrm{~h}$. Then, indole and methyl red tests were applied to determine the presence of E. coli (Wehr and Frank, 2004).

Enumeration of Yeasts and Moulds: Yeasts and moulds were numbered using Potato Dextrose Agar (PDA) (Merck, Darmstad, Germany) which was acidified with tartaric acid $(10 \% \mathrm{w} / \mathrm{v})$. One $\mathrm{ml}$ tartaric acid was used per $100 \mathrm{ml}$ PDA and tartaric acid was added to PDA just before pouring. The inoculated plates were incubated aerobically at $25^{\circ} \mathrm{C}$ for 5-7 d (Wehr and Frank, 2004).

Enumeration of total Staphylococci: Total staphylococci were counted on MSA (Mannitol Salt Agar) after incubating the plates aerobically at $37^{\circ} \mathrm{C}$ for $24 \mathrm{~h}$ (Wehr and Frank, 2004).

\subsubsection{Statistical Analysis}

The data were analyzed using SPSS. The Significance of the differences between means was evaluated by Duncan's Multiple Range Test considering $p<0.01$ as significant.

\section{RESULTS AND DISCUSSION}

In Table 1, total solids, fat, $\mathrm{pH}$, acidity and peroxide values of kaymak samples are presented. As is shown, important differences were found in total solids, fat, $\mathrm{pH}$ and acidity values among kaymak samples. No peroxide value was obtained in any sample. These properties especially depend on the quality of the raw milk and cream along with processing conditions. Similar findings on total solids, fat and acidity ratios and $\mathrm{pH}$ values in kaymak were also observed by Çon et al. (2000), Öksüz et al. (2000). Seçkin et al. (2005) also found $60 \%$ and $65 \%$ fat content in commercial kaymak samples.

The highest levels of both total solids and fat contents were obtained in kaymak sample 3 . Fat contents were in the range of $63.00 \%$ and $73.75 \%$ (Table 1). According to Turkish Food Codex (2003), kaymak should have a min of $60 \%$ fat and the fat contents of our samples were higher than this limit.

Acidity was higher in samples 1 and 5 than those found in the others. Similarly, $\mathrm{pH}$ values were lower in samples 1 and 5. There is no limitation for acidity of kaymak in the Turkish Food Codex (2003). According to the Turkish Standart Institute (1975), the lactic acid percent should not be higher than 
$0.225 \%$ in sweet creams, which is the raw material for kaymak.

The microbiological characteristics of the kaymak samples are summarized in Table 2 . Counts of coliform bacteria, total staphylococci and yeast and moulds were between 0-3.38, 0-6.86 and 3.88-7.53 log cfu/g, respectively. E. coli was detected only in one sample. Differences between the log counts of coliform, staphylococcus and yeast and moulds of the kaymak samples were statistically significant $(p<0.01)$. The results are in agreement with those reported on commercial kaymak samples obtained from different regions of Turkey by Yllsay and Bayizit (2002) and Çon et al. (2000).

Coliforms and staphylococci were not detected in samples 2 and 4 . Similarly, the count of yeast and moulds was also lower in samples 2 and 4 . Sample 3 , contained the highest count of coliform, had $E$. coli. This finding was also observed by Yilsay and Bayizit (2002).

All samples were above the limits established by Turkish Food Codex (2003) for yeasts and moulds. According to Turkish Food Codex (2003), counts of yeast and mould should be $\leq 3$ log cfu per gram of kaymak. Samples 1, 3 and 5 contained higher counts of total coliform and staphylococcus than the mentioned limits. In terms of E. coli, all samples were in compliance to the Turkish Food Codex, except sample 3 .

On the whole, the results indicated that the chemical properties of commercial kaymak samples are acceptable according to Turkish Food Codex (2003). However, the microbial load of most the samples indicates a poor hygienic quality of kaymak, probably due to contamination during the manufacturing process and / or further handling procedures.

In order to improve the safety of the products good manufacturing practices (GMP) including the application of HACCP will have to be introduced to kaymak producing plants. Products similar to kaymak are produced in other parts of the world where the manufacturing process and product quality may vary considerably. As majorities of these traditional products have not been sufficiently studied, more research should be conducted.

Table 1

Total solids, fat, $\mathrm{pH}$ and acidity values in kaymak samples*

\begin{tabular}{cccccc}
\hline Sample No & Total Solids (\%) & Fat (\%) & pH & Acidity $^{\star \star}$ & Peroxide value \\
\hline 1 & $68.43 \pm 0.04^{\mathrm{c}}$ & $64.00 \pm 0.71^{\mathrm{c}}$ & $6.21 \pm 0.14^{\mathrm{c}}$ & $0.13 \pm 0.03^{\mathrm{b}}$ & $\mathrm{ND}$ \\
2 & $74.00 \pm 0.994^{\mathrm{b}}$ & $68.00 \pm 0.71^{\mathrm{b}}$ & $6.90 \pm 0.00^{\mathrm{b}}$ & $0.09 \pm 0.01^{\mathrm{c}}$ & $\mathrm{ND}$ \\
3 & $77.55 \pm 0.21^{\mathrm{a}}$ & $73.75 \pm 0.35^{\mathrm{a}}$ & $6.88 \pm 0.04^{\mathrm{b}}$ & $0.10 \pm 0.01^{\mathrm{bc}}$ & $\mathrm{ND}$ \\
4 & $67.80 \pm 0.42^{\mathrm{c}}$ & $64.50 \pm 0.70^{\mathrm{c}}$ & $7.20 \pm 0.04^{\mathrm{a}}$ & $0.08 \pm 0.01^{\mathrm{c}}$ & $\mathrm{ND}$ \\
5 & $68.30 \pm 0.99^{\mathrm{c}}$ & $63.00 \pm 0.28^{\mathrm{c}}$ & $6.20 \pm 0.21^{\mathrm{c}}$ & $0.20 \pm 0.02^{\mathrm{a}}$ & $\mathrm{ND}$ \\
\hline
\end{tabular}

${ }^{a-d}$ Means in the same column with different letters show significant differences $(p<0.01)$

*Values are expressed as mean \pm Standard deviation

${ }^{* *}$ Acidity are expressed as lactic acid (\%)

ND: non determined

Table 2

Counts of Coliform, Staphylococcus and Yeast and mould in kaymak samples*

\begin{tabular}{ccccc}
\hline $\begin{array}{c}\text { Sample } \\
\text { No }\end{array}$ & $\begin{array}{c}\text { Coliform } \\
(\log \mathrm{cfu} / \mathrm{g})\end{array}$ & $\begin{array}{c}\text { Staphylococcus } \\
(\log \mathrm{cfu} / \mathrm{g})\end{array}$ & $\begin{array}{c}\text { Yeast and mould } \\
(\log \mathrm{cfu} / \mathrm{g})\end{array}$ & E. coli \\
\hline 1 & $2.38 \pm 0.23^{\mathrm{b}}$ & $6.86 \pm 0.04^{\mathrm{a}}$ & $7.53 \pm 0.01^{\mathrm{a}}$ & - \\
2 & $\mathrm{ND}$ & $\mathrm{ND}$ & $5.59 \pm 0.07^{\mathrm{d}}$ & - \\
3 & $3.38 \pm 0.02^{\mathrm{a}}$ & $4.72 \pm 0.00^{\mathrm{b}}$ & $7.15 \pm 0.03^{\mathrm{b}}$ & + \\
4 & $\mathrm{ND}$ & $\mathrm{ND}$ & $3.88 \pm 0.02^{\mathrm{e}}$ & - \\
5 & $1.48 \pm 0.20^{\mathrm{c}}$ & $4.48 \pm 0.03^{\mathrm{c}}$ & $6.12 \pm 0.06^{\mathrm{c}}$ & - \\
\hline
\end{tabular}

${ }^{a-e}$ Means in the same column with different letters show significant differences $(p<0.01)$

*Values are expressed as mean \pm Standard deviation

ND: non determined 


\section{BIBLIOGRAPHY}

Akalın AS, Tokusoglu Ö, Gönç S and Ökten S. 2005. Detection of biologically active isomers of conjugated linoleic acid in kaymak. Grasas y Aceites 56, 298-302.

AOAC. 1990. Official Methods of Analysis, 15th edn. Association of Official Analytical Chemists, Washington DC

Çon AH, Gökçe R and Gürsoy O. 2000. Farkli Şekillerde Ambalajlanan Afyon Kaymaklarinin Muhafaza Sürelerinin Belirlenmesi Üzerine Bir Araștirma. VI. Süt ve Süt Ürünleri Sempozyumu Tebliğler Kitabi, Editör: Mehmet Demirci, 557-564, Tekirdağ.

Fox PF. 1995. Advanced Dairy Chemistry, Lipids, Volume 2, 2nd Ed., Published by Chapman \& Hall, USA.

Hayaloglu AA and Konar A. 2001. A comparative study on physicochemical and sensorial properties of butter made from yoghurt and cream. Milchwissenschaft 56, 675-677.

Kaya A. 2000. Properties and stability of butter oil obtained from milk and yoghurt. Nahrung 44, 126-129.

Metin M. 1998. Süt Teknolojisi. Ege Üniversitesi Müh. Fak. Yayin No:33, Ege Üniv. Basim evi, Bornova-Izmir.

Öksüz Ö, Kurultay S, Simșek O and Gündogdu A. 2000 Tekirdağ İli Merkezinde Üretilen Kaymaklarin Bazi Kimyasal ve Mikrobiyolojik Özelliklerinin Belirlenmesi Üzerine Bir Araștirma. VI. Süt ve Süt Ürünleri Sempozyumu Tébliğler Kitabi, Editör: Mehmet Demirci, 567-570, Tekirdağ.
Sagdıç O, Dönmez M and Demirci M. 2004. Comparison of characteristics and fatty acid profiles of traditional Turkish yayik butters produced from goats', ewes' or cows' milk. Food Control 15, 485-490.

Seçkin AK, Gürsoy O, Kinik Ö and Akbulut N. 2005. Conjugated linoleic acid (CLA) concentration, fatty acid composition and cholesterol content of some Turkish dairy products. LWT Food Sci. Technol. 38, 909-915.

Sserunjogi ML, Abrahamsen RK and Narvhus J. 1998. A Review Paper: Current Knowledge of Ghee and Related Products. Int. Dairy J. 8, 677-688.

Turkish Food Codex. 2003. Cream and Kaymak Document. Ministry of Agriculture and Rural Affairs, Ankara.

Turkish Standards Institute (TSE). 1975. Turkish Standards 1864, Ankara.

Wehr HM and Frank JH. 2004. Standard Methods for the Examination of Dairy Products. 17th Ed., Published by American Public Health Association, New York, USA.

Yılsay TÖ and Bayizit AA. 2002. Bursa İlinde Tüketilen Kaymaklarin Mikrobiyolojik Özellikleri ve Bazi Patojen Bakterilerin Aranmasi. Uludağ Üniversitesi Ziraat Fakültesi Dergisi 16, 77-86.

Recibido: Enero 2006 Aceptado: Agosto 2006 